\title{
He Wā Tuku Reo: Giving Voice to Māori in the Grand Narratives of Colin McCahon
}

\author{
MATARIKI WILLIAMS
}

\begin{abstract}
In the extensive literature surrounding McCahon and his work, his engagement with te reo and te ao Māori has been considered by both Māori and non-Māori authors, who have offered contrasting perspectives on this issue. This article will compare these perspectives and argue that some Pākehā commentators have failed to understand the perspectives of Māori authors who have been critical of his engagements with Māori language and culture. Further, this article will examine the framing of the Māori critique of McCahon in the broader context of his status as New Zealand's most written about, exhibited and celebrated artist.
\end{abstract}

\section{Introduction}

In 1986, Ngahuia Te Awekotuku (Te Arawa, Ngāi Tūhoe, Waikato) was interviewed by Elizabeth Eastmond and Priscilla Pitts in the feminist magazine Antic about the intersections of art, gender, and te ao Māori (the Māori world, encompassing a Māori worldview). A discussion in the interview has Te Awekotuku referring to men assuming the arts of women, which she has problems with, before segueing into a further issue of Pākehā artists taking from te ao Māori:

Yes, it's such a taking situation-and because the Māori world is still heavily under siege, we are still a threatened society in many ways, we are consolidating our resources, we are reclaiming our strength, we are measuring our power, we are, in many ways, caught up in this struggle and so we need to sustain our resources and not lose them. ${ }^{1}$

This "taking situation" is a recurring theme in the work of Colin McCahon-one of the artists to whom Te Awekotuku refers in this interview ${ }^{2}$ - who frequently took from Māori in his works, at least when considered from a Māori perspective. In her interview, Te Awekotuku gave The Canoe Tainui (1975) as one example of such taking, a written painting by McCahon, the text of which was copied from The Tail of the Fish (1968), a book by Te Aupouri kuia (woman elder of Te Aupōuri) Matire Kereama. However, she could just as easily have mentioned other works by McCahon that engage with te reo (the Māori language) and te ao Māori. These include his Scared (1976) series, other works inspired by Kereama's book, and Urewera Mural and other Te Urewera-related works (1975).

In the extensive literature surrounding McCahon and his work, his engagement with te reo and te ao Māori has been considered by both Māori and non-Māori authors, who have offered contrasting perspectives on this issue. This article will compare these perspectives and argue that some Pākehā commentators have failed to understand the perspectives of Māori authors who have been critical of his engagements with Māori language and culture. Further, this article will examine the framing of the Māori critique of McCahon in the broader context of his status as New Zealand's most written about, exhibited and celebrated artist.

Later in this article I present an excerpt from Ngahuia Te Awekotuku who states her position from an iwi (tribal in a Māori sense of familial grouping), gender and professional sense, before offering her perspective on Colin McCahon's work. This is an inherently Māori approach, and 
one that reflects our practice of mihimihi, to introduce oneself to others in order that others may know who one is. In light of that, the following is mine. He uri ahau nō Ngāi Tūhoe, Ngāti Whakaue, Ngāti Hauiti me Taranaki. I tipu ake au i roto i a Tauranga Moana tata atu ki tōku ūkaipō, ko Rūātoki tērā, te whenua i pūritia, te whenua i tāwhia. Kei Te Whanganui-a-Tara ahau e noho ana, e mahi ana ahau ki Te Papa Tongarewa i roto i te tīma Mātauranga Māori. He Kaitiaki, Kairauhī, Kaituhi ahau. ${ }^{3}$

\section{McCahon's Bicultural Nation}

On the occasion of the Museum of New Zealand Te Papa Tongarewa's twentieth birthday, a podcast series was released, titled Ours: A Podcast of Twenty Te Papa Objects. It highlighted twenty taonga (treasured objects) and objects from the national collection in conversations hosted between an internal staff member and an external expert. Amongst the twenty selected objects was the McCahon painting Scared (1976), which was discussed by then Senior Art Curator, Sarah Farrar, and art critic Antony Byrt. The following comments by Byrt provide insight for understanding the way in which Pākehā commentators have ascribed a sense of burgeoning national identity to McCahon's work:

That's really where it became interesting. He started to embrace this combination of Old Testament language, Māori mythology, Māori custom, all these sorts of things to start to understand who the "I" was and where he stood. But of course, in doing that, the "I" comes to stand for all of us who are a product, I think, of this traumatic collision between two cultures and that's why I think McCahon's work is a problem, because New Zealand is forever a problem as well, it's a very unresolvable thing. And so New Zealand culture really, I think, is something that we struggle to describe, that happens on the surface of that scar. You know that's really, that moment of collision between two cultures, that scar, he articulates almost better than anyone else I think. ${ }^{4}$

Byrt's assumption that McCahon and his works can respond to what has happened in Aotearoa in a way that represents all of our history, and that we in Aotearoa could ever be a collective "I" will continue to be challenged by Māori, as will become evident through this article's explorations of Māori reactions to McCahon's works that engage with Māori themes.

This "collision between two cultures" that Byrt sees in McCahon's works with Māori themes is shared by several of McCahon's other supporters, who see in those works evidence of the artist's commitment to biculturalism. For example, in the exhibition catalogue for City Gallery Wellington's 2017 exhibition On Going Out with the Tide, the curators, Robert Leonard and Wystan Curnow, observe:

McCahon's knowledge and understanding of Māori culture was partial and piecemeal. He related to Māori ideas through their spirituality, either seeing Christian and Māori ideas as parallel or looking to the hybrid forms of Māori Christianity. His biculturalism was entangled with his Christianity, which has been seen as limiting it. ${ }^{5}$

The same catalogue describes McCahon's 1974 work, The Song of the Shining Cuckoo, as "bicultural" in that "it suggests distinct and not necessarily compatible ideas concerning death and the afterlife - Christian and Māori." This particular work was inspired by the words from a waiata (song) that artist Ralph Hotere (Te Aupōuri, Te Rarawa) received from his father Tangirau and passed on to McCahon with the suggestion that he could use them. Here, it would have been helpful to have an explanation of what the writers suggest biculturalism is, and expressly what it means in relation to McCahon's work and this work in particular. If the suggestion is that McCahon had developed a personal understanding of biculturalism as it pertains directly to his work, I could abide by that, but the assumption from scholars appears 
to be that his work is imbued with a sense of "biculturalism" due to the societal changes that were occurring at the time of its making. As Leonard and Curnow extrapolate:

On Going Out with the Tide addresses McCahon's works on Māori subjects and themes from the 1960s and 1970s.... On Going Out with the Tide, then, is an opportunity to consider how things Māori influenced the most important period of New Zealand's most celebrated artist. Now, in the twenty-first century, we can understand this work in terms of a tectonic shift in New Zealand culture-emerging biculturalism. ${ }^{7}$

What is the "emerging biculturalism" that Leonard and Curnow are referring to here? The rise in Māori protest voices and movements? If so, it would have been beneficial for the two authors to illustrate how they believe that McCahon's taking of te reo Māori and iwi whakapapa (iwi genealogical connections) for use in his paintings can be considered as supporting Māori causes.

More recently, Justin Paton has also referred to McCahon's biculturalism in the context of his painting The Canoe Tainui (1969), which features text taken from Kereama's book: "But the moment that yields the mighty Practical religion also produces another wordscape, one that feels, from the perspective of a bicultural twenty-first century Aotearoa, especially charged, unsettled and generative." "The wordscape referenced by Paton here is McCahon's The Canoe Tainui (1969), the text of which is taken from Kereama's book. Regardless of what state of biculturalism we are in, in the twenty-first century, this painting was also not roundly well received in its time. It is gratifying to see an acknowledgement from Paton of the unresolved nature of biculturalism today.

To continue with twenty-first century perspectives on McCahon and his legacy, also published in McCahon's centenary year was an article on McCahon's legacy from the artist and art lecturer Shannon Te Ao (Ngāti Tūwharetoa, Ngāti Wairangi, Te Pāpaka o Māui). In the article, Te Ao questions the position McCahon continues to hold in the New Zealand art historical canon, deftly illustrating how the arguments that were originally raised by Māori critics at the time of the painting of The Canoe Tainui continue to resonate. On this point, and with reference to On Going Out with the Tide, Te Ao reflects:

Other works in this exhibition engaged histories and whakapapa with a freedom that is not his to wield. I've had people who are tied to some of these histories point out errors and usage that belittles the tūpuna named throughout these works. What was once excusable in light of good intentions and the avant-garde ethos is now culturally and politically incorrect. It is no longer acceptable to legitimise appropriation, misuse or misrepresentation. What narrative does McCahon's legacy serve? In 2019, I struggle to see how his work can truly embrace all that Aotearoa has become. ${ }^{9}$

Te Ao's appraisal of McCahon's biculturalism contrasts starkly with those of Byrt, Leonard, Curnow and Paton. Te Ao clearly states the way that he and other Māori doubt the claim that McCahon can be seen as bicultural.

\section{Māori Writing about McCahon}

In researching this article, it quickly became apparent that most of the writers who make claims about McCahon's ability, to borrow from Te Ao, to "embrace all that Aotearoa has become," are Pākehā, and those who feel differently are Māori. This is especially problematic in light of 
efforts by these writers to uphold McCahon's legacy as New Zealand's most celebrated artist, a position that, as Te Ao observes, should be seen as problematic in 2020:

[McCahon's] work maintains a position and cultural outlook that no longer serves his presumed audience, or the true fabric of discourse here in contemporary Aotearoa. McCahon is our most celebrated artist because those with the power and privilege continue to attribute this honour to him. This in itself is not inherently problematic. But the default referral to McCahon underlines the need for more appropriate, contemporary and diverse cultural representation. ... The maintenance of a dominant, male Pākehā narrative no longer satisfies any inclusive representation of our collective consciousness or being. ${ }^{10}$

As Te Ao so eloquently states, McCahon's position as New Zealand's most celebrated artist was wilfully constructed by people with powerful roles in academia or the art world. This position is reified by these same people who produce countless McCahon-focused publications, exhibitions and articles. What Te Ao is calling for is a more diverse representation of artists in the canonical accounts of New Zealand art history. In this article, my challenge to those writing into the canonical accounts of New Zealand art history is that it be more inclusive of Māori perspectives when reifying McCahon's position inside it. I further challenge those who reify McCahon's canonical position to reflect on their roles in maintaining McCahon's position.

I turn now to some of the few instances where Māori have offered perspectives on McCahon's work. ${ }^{11}$ The first is from the late art historian and curator Jonathan Mane-Wheoki (Ngāpuhi, Te Aupōuri, Ngāti Kurī, England) who writes that "McCahon had begun to appropriate Māori imagery in 1965, following the example of Theo Schoon, who was now a neighbour in Auckland." 12 The use of the word "appropriate" here is mentioned as if in passing by ManeWheoki, but it is worth pointing out that it is not an adjective preferred by any of the Pākehā writers referenced in this article. Mane-Wheoki uses this term before discussing two of the often-mentioned Māori critiques of Pākehā artists' use of Māori visual languages, that is, of the physical manifestations of Māori culture as seen in ngā toi Māori (Māori artistic practices). These are the aforementioned Antic interview with Te Awekotuku, and the seminal essay, "Māori: At the Centre, On the Margins," for the Headlands catalogue by art historian Rangihiroa Panoho (nō ngā iwi ō Te Tai Tokerau). ${ }^{13}$

It is important to note here how several Pākehā authors have described Te Awekotuku when referring to her criticisms of McCahon's work. Curnow and Leonard describe her as an "academic" who "criticised McCahon for quoting whakapapa in his 1969 painting The Canoe Tainui, considering it culturally insensitive." ${ }^{14}$ In the second of his two-volume survey of McCahon's work, Peter Simpson refers to her as a "radical Māori feminist" who criticised the "cultural inappropriateness" of both The Canoe Tainui and The Canoe Mamari (1969). ${ }^{15}$

Both of these sources also mention Panoho's Headlands essay. Curnow and Leonard present Panoho's critique of McCahon's use of Māori visual languages as favourable in contrast to how he had interpreted Gordon Walters' use, that is, as cultural misappropriation. ${ }^{16}$ Simpson's publication also includes a reference to Panoho's essay, describing Panoho as a "critic," as opposed to an art historian, and interpreting his essay as follows:

This exhibition became controversial especially for an attack on the abstract artist Gordon Walters. ... According to Panoho, Walter's approach [to Māori imagery] manifested "residual colonialism," where he found the use of Māori materials by other Pākehā artists such as Theo Schoon and McCahon more "empathetic," though McCahon was still "essentially an outsider to a culture he admired."17 
Though Panoho was more appreciative of McCahon's approach to using Māori visual languages, I would like to point out that his assessment of McCahon wasn't wholly positive. Indeed, the excerpt from Simpson shows that Panoho still saw McCahon as being an outsider to Māori culture, a culture he still willingly took from.

Simpson's description of Te Awekotuku as a "radical Māori feminist" is reductive. Te Awekotuku has worked across the arts and cultural sector in various roles including as a curator and an art history lecturer, has a proud activist history as a member of Ngā Tamatoa and has played a significant role in terms of gay and lesbian rights, was active in the Māori Artists and Writers Society (later Ngā Puna Waihanga), and has worked in various professorial and teaching roles across academia. This is not to say that Te Awekotuku is not a radical Māori feminist, but rather that Simpson's description comes across as a deliberate way of undermining the breadth of her work. It is worth noting that elsewhere on the same page of his book, Simpson does not characterise Francis Pound and Sarah Hillary in terms of their ethnicity or political perspectives when discussing their contributions to discussions of McCahon's work. That he does so in the case of Te Awekotuku and describes her as a "radical", suggests he has positioned her in this way in order to discredit her opinions.

It is curious that Te Awekotuku's criticisms of McCahon, which are drawn from just one passage of her Antic interview, are mentioned by Leonard, Curnow and Simpson, but that none of her kōrero (statement) elsewhere in the interview about where her position as a critic comes from is ever included. An explicit declaration of her position is mentioned in another interview, conducted the following year, which is also not referenced by any of the sources above. Her language is considered and respectful as she states both her position as a qualification for why she interprets his work the way she does, while also acknowledging she is indeed a fan of his work,

First of all, I've got to mihi to Colin, to McCahon and say that I am one of his most avid and devoted fans and I respect and acknowledge his genius. For me, he is the New Zealand painter and so it is with considerable reservation and regard for him that I am critical of something that he has done. However, I believe that I am speaking not only for myself as a Māori, and as a descendant of Tainui too but I am speaking on behalf of a vast number of others. And having prefaced it that way, I will say that although the painting was done over twenty years ago, The Canoe Tainui does in many ways breach and contravene some dimensions of our lives that we hold very dear. People will say to me, "well genealogy, whakapapa, is available in books, you can pull it out of anywhere, it is yet another resource that you can pick out and write a poem or paint a pictures so what's the difference?" And to that I reply that with The Canoe Tainui and the taking of the whakapapa in that way, we are presenting the lineage and the people in a very brazen way. There is an immediacy in presenting the image in that way, whereas in the verbal imagery and the poetry and in the chant, even in the actual book form, literary form nevertheless, there is a process of distillation and carrying through then either reading out or recitation that takes the immediacy away. It is very different to listening to someone either reciting the genealogy in the correct context, like on the marae. There is a major difference to that and to having those names of those from who you are descended and from whom others are descended quite literally flung onto a wall. ${ }^{18}$ 
This passage is presented in its whole state as there is no other way to preserve the strength of what Te Awekotuku had to say in regards to how her identity informs her position of criticality, and thus in how it determines the conviction of her perspective on McCahon. To read the many ways that she qualifies her opinion on McCahon, before then offering it, and then to read this labour of hers be reduced to "radical Māori feminist" is quite astounding. In contrast, I query why those who decontextualize her declared position when they reference the quotes they do, do not deem it necessary to make such declarations about why their opinion on McCahon is valid in the same way that Te Awekotuku does. Some reflexivity from these authors wouldn't go amiss.

Furthermore, these references also do not cite Te Awekotuku's description elsewhere in the interview of the impact the reaction to her comments elicited: "After my criticism of that work [The Canoe Tainui] I was quite literally ploughed up into a corner and I was offered various explanations by McCahon disciples, and so I've heard the whole range of justifications-none of which I can accept completely." 19 I would suggest that this ploughing into a corner, the selective use of Te Awekotuku's interview and apparent disregard of her expertise, continues every time that the 1986 Antic interview is referenced without regard for Te Awekotuku's description of her position as a Māori, a woman, a Māori woman who draws whakapapa to Tainui, and as a curator.

\section{Te Ao Māori and Voicelessness}

In addition to Māori commentators on McCahon's Māori-related work who have had their opinions marginalised or misrepresented by Pākehā writers, there are many other Māori whose opinions on this work remain unknown because they were never solicited. The fact that these figures, some of whom were members of McCahon's own family, have not had their voices added to the historical record reinforces the lack of agency Māori have had in the way McCahon himself wrote about Māori and how later historians have discussed his engagements with Māori language and culture.

As Mane-Wheoki noted in 2003, McCahon was friendly with a number of Māori artists, including Buster Black (Pihama), a Taumarunui-born artist of Ngāti Maniapoto and Ngāti Rangi whakapapa, and Ralph Hotere. ${ }^{20}$ But these connections notwithstanding, "much of the knowledge McCahon came to acquire about te ao Māori derived from conversations and correspondence with his great friend the poet John Caselberg." 21 


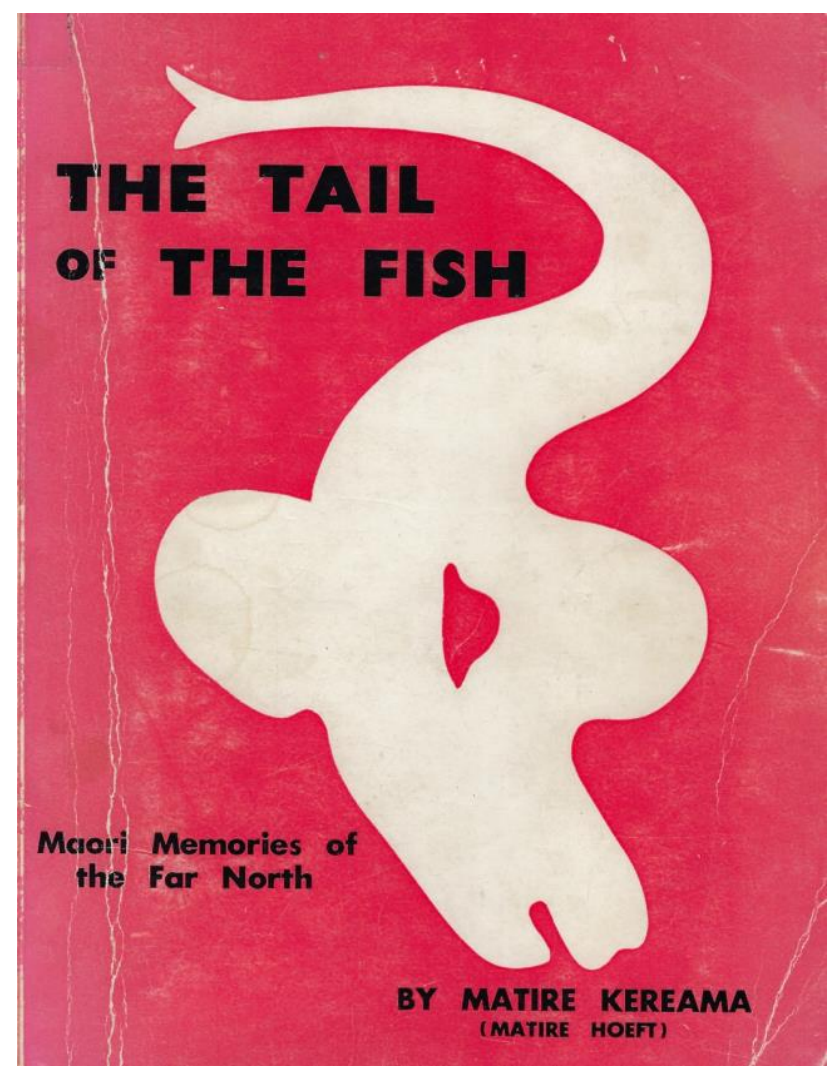

Figure 1. Matire Kereama, The Tail of the Fish. Maori Memories of the Far North, Oswald-Sealy, Auckland 1968.

It is rather alarming that McCahon so often sought information about te ao Māori from a nonMāori acquaintance rather than from Māori with whom he had existing relationships. Yet in contrast to Mane-Wheoki, who questioned this decision, some other writers have not voiced this concern. Instead, they have focused on two events that they see as significant catalysts for McCahon's engagement with aspects of te ao Māori, while passing over his engagement with Caselberg. The events in question are the gifting of Kereama's book to McCahon by his daughter Catherine, and the birth of his grandchild whose father was from Tainui. The points are often mentioned, either separately or jointly, without looking at the broader history of his knowledge acquisition as being from non-Māori.

In the On Going Out with the Tide catalogue, Leonard and Curnow refer to both of them:

In 1968, McCahon's daughter Victoria and her Tainui husband Ken Carr had a son, Matiu. Around this time, his other daughter, Catherine, gave him a copy of a new book, The Tail of the Fish: Māori Memories of the Far North. . . . Together, grandson and book prompted McCahon to return to Māori subjects. ${ }^{22}$

In McCahon Country, Paton refers only to the birth of Matiu, noting that "this happy moment in his personal life sparked a deeper engagement with te ao Māori, giving rise to paintings whose borrowings are, today, among the most debated aspects of McCahon's legacy.",23

In Colin McCahon: Is This the Promised Land? Vol. 2 1960-1987, Simpson represents these events thus: "The birth of his first grandson Matiu to his second daughter Victoria (Tora) and her husband Ken Carr, from a prominent Waikato Māori family ... gave a fresh boost to 
McCahon's already strong interest in Māori culture, an interest further enhanced by his daughter Catherine's gift." 24

In Colin McCahon: Artist, Gordon H. Brown positions these two events as follows:

Things Māori dimmed for a time, then were revived early in 1969 after McCahon had read Matire Kereama's The Tail of the Fish.... Some months before Catherine McCahon had made her father aware of Matire Kereama's book, his other daughter, Victoria, had given birth to a son, Matiu (Mrs Carr's husband is Māori). ${ }^{25}$

In the publication released to accompany the exhibition Colin McCahon: A Question of Faith, the chronology compiled by Marja Bloem and Martin Browne, also makes mention of these two events,

Closer to home, 1969 saw McCahon re-engage with Māori culture in the first significant way since 1965. In part this was the result of his daughter Victoria's marriage to Ken Carr, a member of a prominent Māori family, and, subsequently, the birth of their first child. These events prompted McCahon's interest in the genealogy and culture of his Māori relatives, a development that coincided with an increased consideration of Māori issues generally amongst New Zealanders at that time. ${ }^{26}$

Despite the many times these two events are mentioned, it is worthwhile noting that at no point are McCahon's son-in-law Ken Carr, his mokopuna (grandchild), or Matire Kereama ever given a voice beyond that which is either ascribed to them via their relationship with McCahon or, to reference Te Awekotuku's earlier point about "taking," that which he takes from them.

This is not a judgement of McCahon as a father-in-law or as a grandfather. I wouldn't presume to have an insight into their whanau (family) dynamic; rather, it is a question that needs to be asked of the writers and curators who continue to present the same events in the same way. None of the passages above present any information that distinguishes them from each other; it as if the way these events are framed, anecdotes that contribute to the story of McCahon as an artist, do not require further question. Although these events happened over 50 years ago, it is unfortunate that there is no insight into the perspectives of Kereama's whannau or the members of the wider McCahon family who are mentioned.

\section{McCahon and Matire Kereama}

This essay now returns to the paintings inspired by Kereama's book, and the taking of her words by McCahon for The Canoe Tainui. It is shocking to read his impression of the whakapapa she included in her book as being inaccurate. As he wrote in a letter to Caselberg in 1969:

Have you met with (and if so can you give me any information about) Matire Kereama's . . book "The tail of the Fish." I've been extracting words from that doing translations??? \& painting genealogies.... These are very inaccurate genealogies, they overlap-tribe joins tribe \& family family. etc. etc. ${ }^{27}$

As much as McCahon scholars describe the artist's admiration of Kereama's book, this was the first mention I'd seen of him describing the whakapapa as inaccurate. As a counterpoint, I offer the poetic interpretation by the writer, former librarian and restorative justice worker, Anne Waapu (Rongomaiwāhine, Ngāti Kahungunu, Te Āti Haunui-a-Pāpārangi), in which whakapapa is described as "a series of never-ending beginnings". This phrase is itself taken from kōrero between Waapu and the celebrated constitutional reform advocate, Moana Jackson (Ngāti Kahungunu, Ngāti Porou). ${ }^{28}$ This series of never-ending beginnings references the 
lateral nature of whakapapa, with branches joining others and new iwi, hapū and whānau being created. From a Māori point of view, this is not an inaccuracy; our whakapapa is not wrong, it is an acknowledgement of the many unions that bind us and that whakapapa is not a simple, top-down exercise. In McCahon's interpretation of whakapapa as inaccurate we see another example of McCahon taking without context or input. It is also precisely because of whakapapa, which The Canoe Tainui depicts, that Māori reactions to that painting are so visceral. Whakapapa, and in this case ancestral waka (canoe) tie Māori not only to other Māori who descend from those waka, but they also connect us back to the wider Te Moananui-a-Kiwa (body of water also known as the Pacific Ocean). In the aforementioned practice of mihimihi, waka are often also mentioned.

A page after his description of the birth of McCahon's grandchild, , Simpson offers further explanation of McCahon's process in the making of The Canoe Tainui,

McCahon talked or changed his text paintings as he painted them. Although he could not speak te reo, he nutted out translations from dictionaries.... It is possibly McCahon's most profound act of imaginative identification with Māoritanga, arguably among the most profound ever achieved by a Pākehā artist. ${ }^{29}$

It is apparent that McCahon didn't see his lack of skill in te reo Māori as a limitation for arranging the names of tippuna (ancestors) that he included in his painting. Indeed, in spite of this lack of skill, many of his proponents applaud his use of te reo and other aspects of te ao Māori as a positive aspect of his work.

One technique for which McCahon has been lauded is a method for implying spoken emphasis in his work. This has been interpreted as McCahon's way of giving due respect to the art of oratory, and the oral nature of Māori culture. McCahon's emphasis, as determined by words painted in bold, assumes a familiarity with the texts he has painted that he admittedly didn't have, due to his lack of understanding of te reo Māori. For Curnow and Leonard, this is described as him emphasising "the oral basis of Māori expression." ${ }^{30}$ With Paton, this acknowledgement of oral culture is evocatively described as follows: "The reo unfurls in a steady ebb and flow that visualises the momentum of oratory. The words softening and then regaining volume with each new breath of the speaker, and many small painterly amendments and adjustments that weight and tune the intonation." ${ }^{31}$ Curnow, in the catalogue for I Will Need Words: Colin McCahon's Word and Number Paintings, writes about McCahon's engagement with te reo and genealogy:

McCahon, too, tells stories of ancestors by writing them down. . . . It is important to stress that he is not the author of the texts he uses. For all that he approves of them, identifies with them, talks them to himself, he did not write them.... He presents himself as a recipient of the language — as he is the recipient of all the signs, symbols, conventions that form the content of his work. ${ }^{32}$

My interpretation of McCahon's use of these "texts" differs from Curnow's. I argue that ancestral stories are being told by their uri (descendants) who are the recipients of this content by nature of their whakapapa. I would also suggest that assuming McCahon to be a "recipient" of all that informs his work ignores the way in which Māori have contested his open-access use. These ancestral stories are not McCahon's to tell; his evidential non-fluency in te reo Māori also means that his understanding of how to tell them is also in question. 
Alongside these interpretations of McCahon's use of text, my assessments focusing predominantly on the use of Māori texts, another event highlights both his appreciation of Matire Kereama's work and his lack of personal engagement with her. There are multiple mentions among the various McCahon publications of a visit Kereama is reported to have made to view The Lark's Song when it was exhibited in Auckland. In McCahon Country, Paton writes that Kereama was said to have visited the painting and "performed" with it. ${ }^{33}$ It is unclear from this description whether or not this was an organised event or whether she visited without announcement. My guess is the latter, given that there is no further discussion proffered about her visit beyond the detail of her reciting the words from the canvas. This event is also mentioned in Simpson's book as well as in Curnow and Leonard's catalogue, both of these citing the same reference from Gordon H. Brown. A more comprehensive recollection is mentioned in Brown's publication, Colin McCahon: Artist:

McCahon states that when The Lark's Song was being exhibited in Auckland, Matire Kereama visited the gallery. Waiting until the room was almost clear of people, she chanted the song. This experience helped McCahon to a deeper understanding of the song, its meaning and the subtlety of its poetical sounds and rhythms. ${ }^{34}$

As profound as this encounter sounds, it is unfortunate that Kereama herself is not quoted by Brown and it seems that her own perspective seems not to have been solicited. What was this experience like for her, to see her words replicated on canvas in this way? Bearing in mind that McCahon's painting techniques are used to imply spoken emphasis, did his interpretation of Kereama's kōrero fit with where her emphasis sat? When singing waiata Māori, the rangi (melody) of the song is crucial, as starting or finishing a line without others could mean an unanticipated solo. This is why emphasis in the right place is important. Regardless of whether McCahon did interact with Kereama during her visit to seeing a work inspired by her own, that he didn't know the rangi of the song before painting it is an injustice to Kereama's waiata. 


\section{Scared Series}

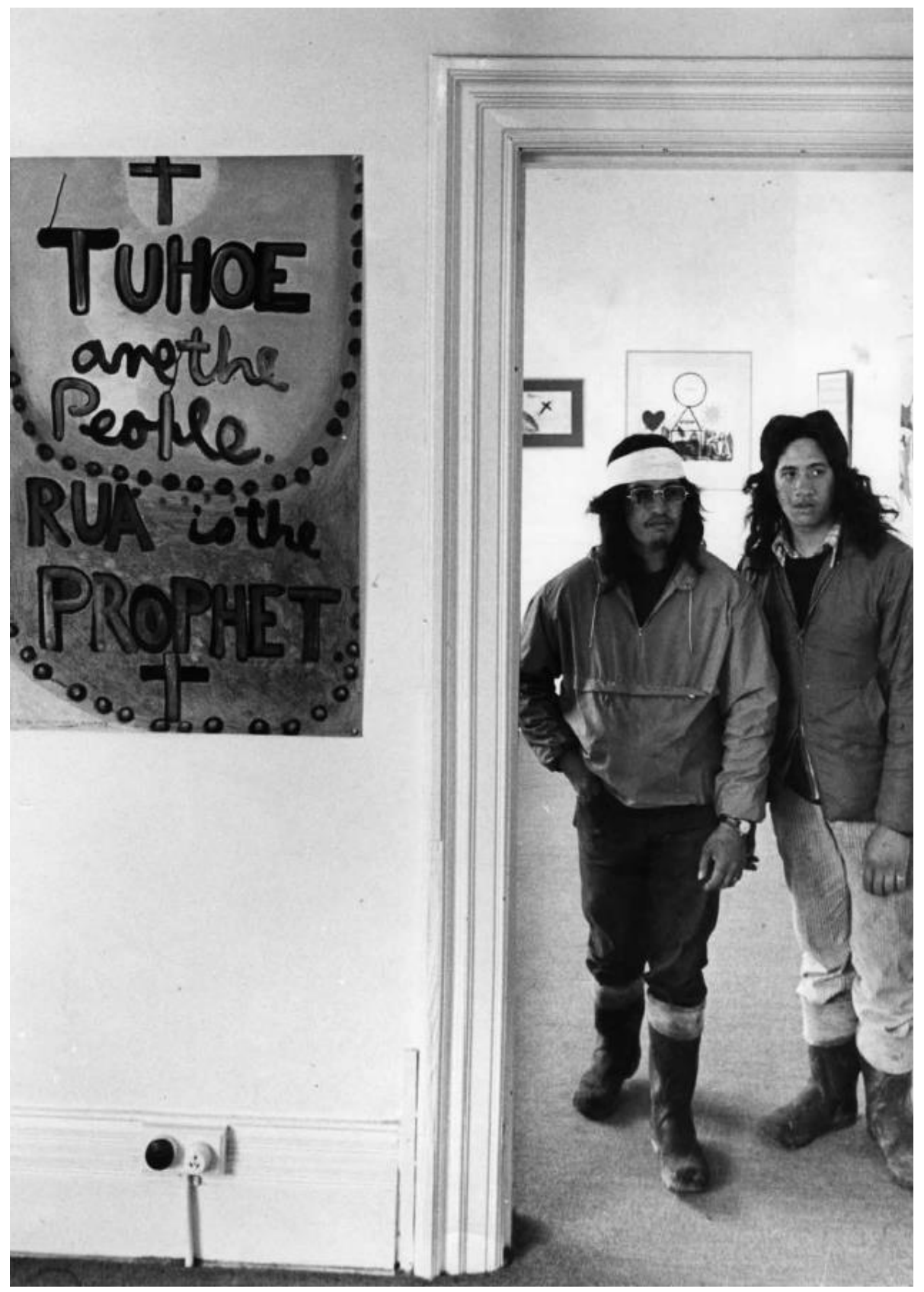

Figure 2. Lionel and Ray Skipper with Colin McCahon's A Poster for the Urewera No. 2 (1975) at Peter McLeavey Gallery, Wellington, December 1975. (Photographer: Don Roy, courtesy of Stuff Ltd.)

The absence of a Māori voice is also keenly felt in discussions of McCahon's Scared series. In much the same way that the unquestioned lore around McCahon's renewed interest in te ao Māori continues to circulate, so too does a story relating to the origins of these works. Simpson describes the series as having been prompted by "a photograph sent to McCahon of two young Māori entering the alien territory of McLeavey's gallery to view the posters in praise of Tūhoe and Rua Kennana." 35 This is followed by the response from McCahon himself as written back to McLeavey, "That photograph again made me feel better. That boy to the right going to 
unexplored land \& the smaller fellow in the middle \& me pushing a message neither of them has seen yet." ${ }^{36}$ It is unclear why, but Simpson's publication doesn't name the two men, though their names, Lionel and Ray Skipper, are included in at least two readily available references to this photograph. ${ }^{37}$ Instead, the image caption simply states: "Māori visitors to the Peter McLeavey Gallery, Wellington, 1975, photograph taken by Don Roy." 38

To Simpson, Lionel and Ray Skipper are entering "alien territory," the implication being that visiting an art gallery is not a regular occurrence for them. According to the Govett-Brewster Art Gallery, the men are "apprehensively entering the unfamiliar environment of an art gallery." ${ }^{39}$ In Jill Trevelyan's observation, unfamiliarity is also mentioned: "McCahon began the 'Scared' series in 1976, after seeing a photograph of two young Māori men, Lionel and Ray Skipper, who had ventured into the unfamiliar environment of Peter McLeavey Gallery in Wellington to see his art. ${ }^{" 40}$ Curnow and Leonard intimate that the men hover with uncertainty at the doorway to the gallery. ${ }^{41}$ It is frustrating that at no point is there a perspective provided from the men in the photograph; as above, it begs the question as to whether or not any of these writers has ever asked for their perspective. In the meantime, the continued interpretations of the men's experience is but projection.

To compound the lack of voice these men have, at no point in these interpretations is there space given as to why each writer would assume the view they attribute to these men. A pause for some reflexivity about why this environment might be alien to the men wouldn't go amiss here, especially if it is linked to how these writers continue to write about the men without their input, and that a celebrated artist then chose to make a series of paintings based on his interpretation of their feelings.

\section{Tūhoe Country}

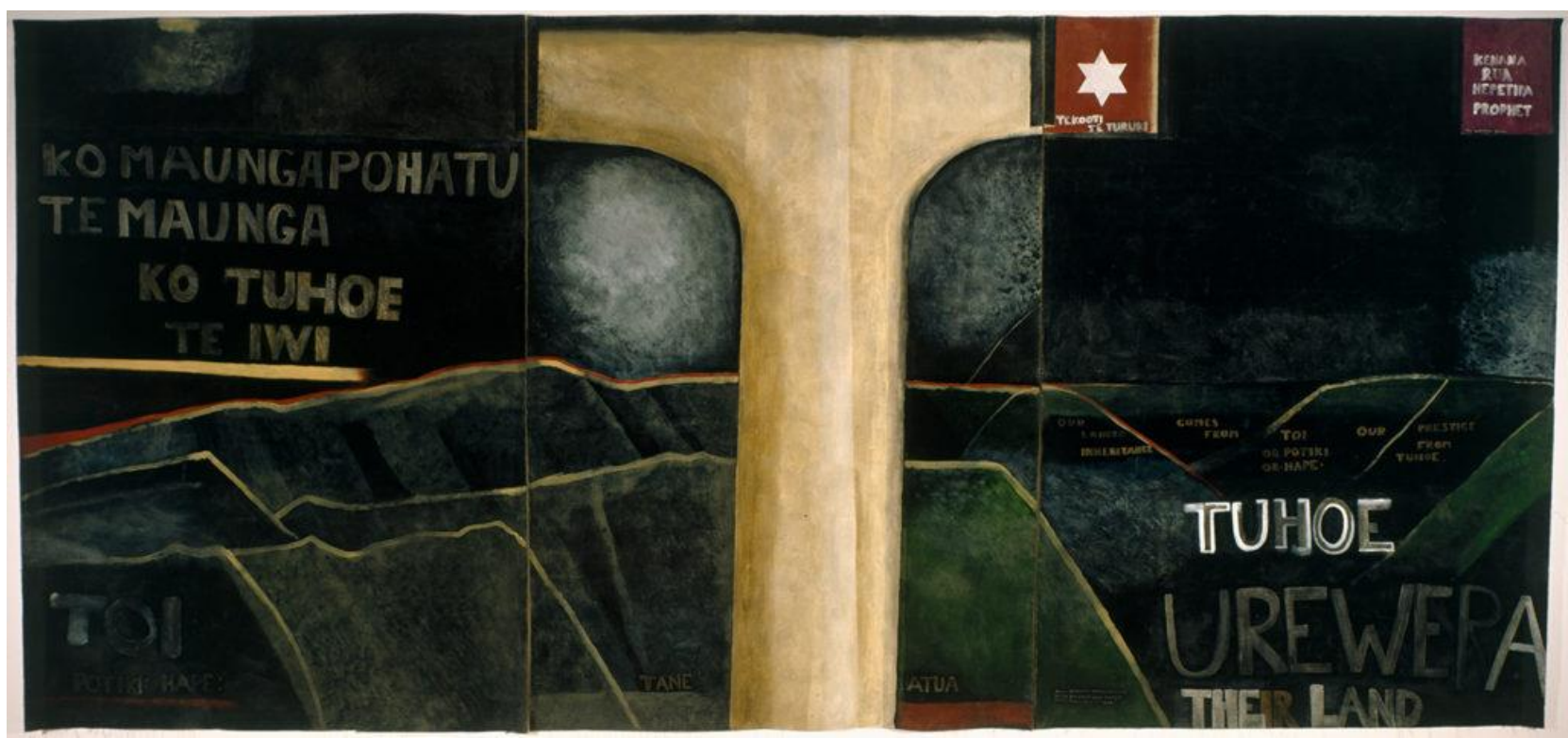

Figure 3. Colin McCahon, Urewera Mural, 1975. Synthetic polymer paint on three unstretched canvases, each 2158 x $182 \mathrm{~mm}$; overall 2158 x $5460 \mathrm{~mm}$. Department of Conservation Te Papa Atawhai and Tūhoe Te Uru Taumatua (courtesy of Department of Conservation Te Papa Atawhai and Tūhoe Te Uru Taumatua). 
The aforementioned authors all assert that McCahon maintained a deep love for the New Zealand landscape, and that this love was a bridge for the artist into his interpretation of aspects of te ao Māori. The controversial paintings he produced in relation to Te Urewera are a notable case in point.

Before discussing the way in which McCahon scholars write about the artist's engagement with Te Urewera, I will foreground some widely available Tühoe perspectives on what it means to be Tūhoe. Indeed, many of these selected perspectives have been published in relation to discussions about McCahon's Te Urewera works. On the occasion of the 1999 hanging of Urewera Mural (1975), curated by then Indigenous Curator Māori Art Ngahiraka Mason (Ngāi Tūhoe) at Auckland Art Gallery, following the painting's theft and return fifteen months later, a small catalogue and accompanying $C D$ was published. The publication presents six perspectives (not including the foreword from director Chris Saines) on the work and its history, three from Tūhoe and three from Pākehā. All of the perspectives offered are male. The following excerpt from Senior Lecturer Māori Studies at Victoria University, Pou Temara, presents his insight into the Tūhoe concept of identity, matemateāone. This concept provided an interpretive device for his engagement with McCahon's Urewera works: "It [matemateāone] is beyond aroha. It is a primal response to and craving for a particular place: a relationship with one's forebears. A sense of timeless belonging, of blood within the earth, across the waves, and in the skies." 42

In their report Ngā Taonga ō Te Urewera, authors Ngahuia Te Awekotuku and Linda Waimarie Nikora (Ngāi Tūhoe, Te Aitanga a Hauiti) include further viewpoints from Tūhoe kaumātua (elders) about the strength of Tūhoe identity. At times they refer explicitly to matemateāone; at other times, it is implicitly acknowledged as an inherent component of an identity that is closely tied to whenua (land) and whānau. Each of these kōrero, shared below, adds a further layer of complexity and depth. From Hēnare Nikora: "Te Urewera is very much part of Tūhoe. If Tūhoe talks to Tūhoe, then you are talking to Te Urewera as well. You cannot separate the two. We are all around and within it. . . Tūhoe and Te Urewera are one. It is incomprehensible to see them as separate." ${ }^{\prime 3}$

Here is Rangimarie Pere's explanation of how being Tūhoe informs aspects of her work as a healer:

A conservationist at heart, I am very grateful that the Urewera bush, the ancestral home of the Tuhoe people, is still intact. The bush clad ranges, the mist, the smell of the undergrowth, the company of birds and insects, Panekire - the majestic bluff that stands sentinel over the tranquil or sometimes turbulent waters of Waikaremoanaall give me a strong sense of identity and purpose to life. ${ }^{44}$

To the rangatira (iwi leader) Erueti Tamaikoha, his identity was veritably forged in the landscape of Te Urewera: "Ko ngā awa teretere, me ngā whārua kuiti aku wao. Ko ngā tokanui me ngā pari tokatoka ōku parepare."

The late Wharehuia Milroy, CNZM QSO, provides the following description of how the concept of matemateāone is at once a collective notion embracing the experience of all Tūhoe and a notion expressed and experienced differently by individuals:

As we understand it, it is a dynamic associated with the manner in which we Tühoe organise ourselves socially, culturally, politically and spiritually. They are our ideals as an iwi, moral dictates that say how we are to behave. Matemateāone grows from within the group, knowing and getting to know each other. The physical cues such as 
trees, mountains, rivers and kāinga etc. are all factors that activate matemāteaone. Everyone of Tūhoe should share a subtle code of knowledge that goes to make up matemateāone. ${ }^{46}$

These few insights are but a fraction of perspectives from Tūhoe as to how identity is formed and defined, identity which is, as Milroy shared, as individually formed as it is collective. These perspectives go some way to account for the way in which McCahon's Te Urewera works were received by Tūhoe.

McCahon recalled his first impressions of Te Urewera in the following letter to Anne Caselberg:

Anne and I have been down to a weekend school in Napier-we came back through the Urewera country in pouring rain, wipers packed up, at least fifty slips, large and small on the road - no tops showing - dark bush and flowing red mud, drifting clouds held between trees - and a great lot of luck not to slide sideways over the edge and down four or five hundred feet into foaming yellow ochre rivers and lakes. Coromandel is a land for beginners, this for those who have learned how to cry. ${ }^{47}$

From this passage, one could possibly infer an affinity on McCahon's part for the way in which Tūhoe view Te Urewera as an entity in and of itself. Its ability to make you cry due to being at the mercy of its power.

Elsewhere, outsider perspectives of Aotearoa equate the absence of humans with emptiness, as shared by Bloem in the catalogue for A Question of Faith:

For the many Europeans - especially British subjects — who arrived in New Zealand from the 1840s onwards, New Zealand was itself a "promised land." It was sensationally beautiful, and although the Māori had arrived long before, around 950 $\mathrm{AD}$, to all intents it was empty when compared to the Europe on the brink of industrial revolution that the settlers had left. ${ }^{48}$

Bloem's description of the land as "empty" contrasts starkly with the way in which the Tūhoe kaumātua quoted above interpret the landscape. To Tūhoe it is full precisely because of rivers, birds, trees, our gods: these elements that are all crucial to the formation of Tūhoe identity.

Ultimately, the greatest test of McCahon's appreciation of Te Urewera is evidenced in the commissioning of the artist by the Urewera National Park Board to create a mural for the Department of Conservation visitor centre at Lake Waikaremoana. It is clear that there was disagreement from the start about the choice of artist, as the late Tūhoe historian, whakapapa expert and former member of the Te Urewera Trust Board Tama Nikora wrote in the 1999 catalogue for Mason's aforementioned Auckland Art Gallery show:

Ka whakaarotia me karanga tētahi tohunga hei mahi i tētahi peita. Ka whakaaro au mō Te Wakaunua, engari ka riro te pōti mō Mākana. Mea ake, ka tae mai te whakaatu ki te Poari kua oti, me ngā whakaahua paku. Ka pātai te Tiamana mō ètahi o ngā mema kia haere ki Tāmaki ki te titiro. Kāre au i haere, he kore nōku e rata ana ki ngā whakaahua paku, anō noa nei, nā te pīpī noa ēnei ūkuikui. .. . E meatia ana tātau me ò tātau tīpuna kei te pōuriuri tonu e kau ake ana. Kātahi ka poau mai te mārama ki waenga. $^{49}$ 
Nikora chose not to travel to view McCahon's paintings, and the issue remained unresolved. In the same passage, Nikora went on to question the text that McCahon chose for his painting, clearly showing how unresolved this discussion was over twenty years after the painting's completion. The other point he makes is that he had advocated for the commission to be completed by Te Wakaunua, the late artist and educator who is also known as Arnold Manaaki Wilson (Ngāi Tūhoe, Te Arawa).

A similar point was also raised by Te Awekotuku in her 1987 interview, and though both she and Nikora mention it, it is not referred to in the publications that have been interrogated in this article. Te Awekotuku states her perspective as follows:

Apart from The Canoe Tainui, there is something else that he has done which I think deserves comment from a Māori, and that is the mural of Waikaremoana which is absolutely magical, which is absolutely brilliant. And yet at the same time I recall when that was unveiled and many of the elders, many of the people were saying "well, why him? Why not a Māori painter?" Because from the Tūhoe Waikaremoana area, we actually do have some fairly outstanding contemporary artists who are known on the art scene. ${ }^{50}$

It is clear from my earlier explorations of McCahon's works in the Scared series, as well as his engagement with Matire Kereama's book if not with her as a person, that McCahon was comfortable creating works that reference things very dear to Māori without the need for consultation with Māori. It is also very apparent from the passages above that, for Tūhoe, this would not suffice. His previous engagements with te reo Māori and te ao Māori, which have been noted as being informed by books, dictionaries and his Pākehā friend, Caselberg, rather than Māori people, mean his skills of engagement would also be insufficient when dealing with Tūhoe histories. As Brown puts this in Colin McCahon: Artist:

Although McCahon had spent considerable effort making sure that the text he had inscribed on the mural was accurate, one member of the park board was unhappy with the words "ko tutakangahau te tangata" and wanted them modified. Although somewhat put out about this, McCahon was willing to make the required alteration. ${ }^{51}$

It is unclear, to me at least, just what this "considerable effort" was, especially as a single conversation could have enlightened him as to why it was inappropriate to give such credence to an individual rangatira.

As Simpson explains, McCahon's difficulties surrounding the commission evolved over time. Though he was initially loathe for the painting to represent idealistic Pākehā views of the region's landscape, requests from Tūhoe to change the text were also met with discontent, as an extract from a letter from McCahon, reproduced in Simpson's book, outlines: "John Rangihau promised me to send the wording change immediately after seeing the mural. I'm a bit disappointed in the new wording. Something is lost \& I feel the new words are to glorify the Tūhoe people (who get good measure as it is)." ${ }^{52}$ Clearly, Tūhoe did not agree that they received good measure in the original wording of the painting. If they had, they would not have requested a change. Historically, they had in no way received good measure from the Crown either, specifically in relation to the "scorched earth" policy at Lake Waikaremoana (1867-71) which razed Tūhoe lands, "destroying 10 Tūhoe kāinga and all cultivations, food stores, livestock, horses, and waka to ensure total suppression of any resistance." ${ }^{, 3}$ The imposition of McCahon's painting upon them by government officials a century later was a further instance of government injustice. All of these instances are connected, and in all of them, Tūhoe wield far less power than those they are pushing back against. 
Despite the commission of an artist whom Tūhoe did not support, and the ensuing issues surrounding requested changes to the text in the paintings, both Brown, and Bloem and Browne, reproduce responses from Pākehā writers that look favourably upon McCahon's Te Urewera works. Brown includes the following comments from a review of Urewera Mural by Neil Rowe: "In this smoulderingly beautiful painting, McCahon depicts the brooding majesty of the Urewera country and also the inseparable bond between the people and the land which is the very essence of Māoritanga and which should be the heritage of all New Zealanders." 54 Equating the bond between Te Urewera and Tūhoe as being "the very essence of Māoritanga" would, I'm sure, be deemed by Tūhoe a misinterpretation of that which is, in fact, the essence of Tühoetanga. To quote the aforementioned Board member who prompted the changes in text from McCahon, the revered late academic John Rangihau, it is his Tūhoetanga that is most influential in the formation of his identity: "Although these feelings are Māori, for me they are my Tūhoetanga rather than my Māoritanga. Because my being a Māori person is absolutely dependent on my history as a Tūhoe person ... Tūhoetanga means that I do the things that are meaningful to Tūhoe." ${ }^{, 55}$ In reading the way that these Tūhoe iwi members describe their identity as inextricably linked to landscape, can one then make the claim that this should be the heritage of all New Zealanders, or should other New Zealanders express that connection in other ways deriving from their own cultural perspectives?

Bloem and Browne quote Gregory O'Brien in the exhibition catalogue for McCahon-A View from Urewera as follows: "A form of activism and, in the artist's words, 'a potent way of talking,' McCahon's Urewera works uphold Māori attitudes to the land and the enduring significance of the indigenous language, as well as specific Māori texts." ${ }^{\prime 56}$ It is clear from the Park Board's minutes, however, that the creation of these works was a constantly fraught process, that "Māori attitudes" to land, let alone those of Tūhoe, were inadequately addressed, and that our language, indeed Tūhoe whakapapa itself, was deployed in a way that did not enhance the mana of Tūhoe. Again, I refer to Pou Temara's text in the Urewera Mural catalogue: "This is what my Te Urewera means to me. This primal sense of belonging and affinity with the land cannot be illustrated by McCahon's Te Urewera, which is devoid of those elements which are meaningful to me." 57 These reviews and responses to McCahon's Te Urewera works, when coming from those outside of Tūhoe, tend to overestimate the artist's ability to faithfully represent what Tūhoe hold so dear. The following passage from Paton however, goes some way to understanding the enduring Tühoe stance in relation to both the works and outsider excursions into Te Rohe Pōtae ō Tūhoe generally:

McCahon's landscapes until this point had proposed a movement from oversight to loving attention: a neglected place brought to light through the noticing devotion of the artist. But what if a place did not need that attention: what if it insisted on being held apart? This possibility crystallised when Tūhoe elders asked for changes to McCahon's text to ensure Tūhoe mana and histories were respected. Two kinds of authority clashed in this moment — cultural and artistic — and a long and often tense correspondence ensued, with McCahon at last agreeing to paint over the disputed text and paint in the words requested: "KO TUHOE TE IWI." For viewers today, however, the most striking textual adjustment is one McCahon intended: the two ghostly letters in the bottom right of the mural which turn "THE LAND" into "THEIR LAND." 58

Paton does well to mention the clash of authority he describes. However, he does not address its unbalanced nature. Why should a single artist's perspective be held up as being of equal import to that of an entire iwi? Given the context of Tühoe experience of colonisation, and the way in which this experience continued in the marginalisation of Tühoe votes in the 
commissioning process that appointed $\mathrm{McCahon}$ in the first place, his begrudging adjustments to his painting read as yet another way in which Tūhoe agency was in the hands of an outsider.

\section{Conclusion}

Before researching this article, my knowledge of Colin McCahon and his specific role in New Zealand art history, beyond his Te Urewera works, was minimal. In his paintings I see his deep love of the New Zealand landscape, and through his writing I read his desire for resolution. In the New Zealand art history canon, he holds a well-constructed and reified position. It is with sadness that I read the way in which Māori who have criticised his work have been marginalised or ignored. When it comes to the Te Urewera works in particular, some of the people quoted are whānau members, so in reading responses to them I am steeled by whakapapa.

This article was not initially intended to be about the way that McCahon scholarship represents the artist's use of Māori visual languages. As I continued to research, I became alarmed at the lack of engagement Pākehā McCahon scholars had with Māori as a living people rather than an abstracted concept to be taken from. The voicelessness of Māori in discussions of McCahon and his work is, ironically, hyper-apparent to me. In McCahon's story, he is always the protagonist. This article has instead made Māori its protagonists, and given voice and prominence to our perspectives.

\footnotetext{
${ }^{1}$ Ngahuia Te Awekotuku, "Ngahuia Te Awekotuku in Conversation with Elizabeth Eastmond and Priscilla Pitts," Antic 1 (1986): 48. Emphasis in the original.

${ }^{2}$ Throughout this interview, Te Awekotuku, Eastmond and Pitts discuss the work of Colin McCahon, Gordon Walters, Tony Fomison, Jan Van de Klundert, Ingrid Banwell, Chris Booth, and Christine Hellyar.

${ }^{3}$ I am a descendant of Ngāi Tūhoe, Ngāti Whakaue, Ngāti Hauiti and Taranaki iwi. I grew up in Tauranga Moana, close to my home of Rūâtoki. I live in Wellington and work at Te Papa in the Mātauranga Māori curatorial team. I am a curator and writer.

4 “'Anthony Byrt and Sarah Farrar on Colin McCahon's 'Scared," Te Papa, accessed September 21, 2020, https://www.tepapa.govt.nz/discover-collections/read-watch-play/history/ours-podcasts/colinmccahon-I-am-scared.

${ }^{5}$ Wystan Curnow and Robert Leonard, "Introduction," Colin McCahon: On Going Out with the Tide Exhibition Guide, 2017, unpaginated.

${ }^{6}$ Curnow and Leonard, "Introduction," unpaginated.

${ }^{7}$ Curnow and Leonard, "Introduction," unpaginated.

${ }^{8}$ Justin Paton, McCahon Country (Auckland: Penguin Books, 2019), 110.

${ }^{9}$ Shannon Te Ao, "The Problematic Legacy of Colin McCahon," The Spinoff, accessed September 21, 2020, https://thespinoff.co.nz/art/21-09-2019/the-problematic-legacy-of-colin-mccahon/.

${ }^{10}$ Te Ao, "The Problematic Legacy."

${ }^{11}$ I do want to note that there are examples of Māori writing on McCahon that are not included in this article. My focus on specific works has meant that I have concentrated on writing about those works. For further Māori writing about McCahon, including essays by Ayesha Green, Emily Karaka, Bettina Bradbury and Kararaina Rangihau, among others, see https://mccahonhouse.org.nz/100/; and Jonathan Mane-Wheoki, "An Ornament for the Pakeha. Colin McCahon's Parihaka Triptych,” in Parihaka: The Art of Passive Resistance, ed. Te Miringi Hohaia, Gregory O'Brien and Lara Strongman (Wellington: Victoria University Press, 2001), 129-38.
} 
${ }^{12}$ Jonathan Mane-Wheoki, "The Resurgence of Māori Art: Conflicts and Continuities in the Eighties," The Contemporary Pacific 1 (Spring 1995): 10.

${ }^{13}$ Rangihiroa Panoho, "Māori: At the Centre, On the Margins," in Headlands: Thinking Through New Zealand Art, ed. Mary Barr (Sydney: Museum of Contemporary Art, 1992), 122-36.

${ }^{14}$ Curnow and Leonard, "Introduction," unpaginated.

${ }^{15}$ Peter Simpson, Colin McCahon: Is this the Promised Land? Vol. 2, 1960-1987 (Auckland:

Auckland University Press, 2020), 350.

16 Curnow and Leonard, "Introduction," unpaginated.

${ }^{17}$ Simpson, Is this the Promised Land, 349.

18 "The Maori View of Colin McCahon," Ngā Taonga Sound \& Vision, accessed September 21, 2020, https://www.ngataonga.org.nz/collections/catalogue/catalogue-item?record_id=215756.

${ }^{19}$ Te Awekotuku, "Conversation," 49.

${ }^{20}$ Jonathan Mane-Wheoki, "McCahon and the Māori "Walk" in Colin McCahon: A Question of

Faith. Papers from a Seminar (Auckland: Auckland Art Gallery, 2003), 53.

${ }^{21}$ Mane-Wheoki, "McCahon and the Māori 'Walk," 53.

${ }^{22}$ Curnow and Leonard, "Introduction," unpaginated.

${ }^{23}$ Paton, McCahon Country, 111.

${ }^{24}$ Simpson, Is this the Promised Land, 96.

${ }^{25}$ Gordon H. Brown, Colin McCahon: Artist (Auckland: Reed, 1993), 157.

${ }^{26}$ Marja Bloem and Martin Browne, Colin McCahon: A Question of Faith (Nelson: Stedelijk Museum and Craig Potton, 2002), 210.

${ }^{27}$ McCahon, letter to John Caselberg, June 1969, quoted in Simpson, Is This the Promised Land, 96.

${ }^{28}$ Anne Waapu, phone call to author, 18 September 2020.

${ }^{29}$ Simpson, Is This the Promised Land, 97.

${ }^{30}$ Curnow and Leonard, "Introduction," unpaginated.

${ }^{31}$ Paton, McCahon Country, 110.

${ }^{32}$ Wystan Curnow, "Untitled," in I Will Need Words: Colin McCahon's Word and Number Paintings (1984), unpaginated.

${ }^{33}$ Paton, McCahon Country, 111.

${ }^{34}$ Brown, Colin McCahon: Artist, 230.

${ }^{35}$ Simpson, Is This the Promised Land, 261.

${ }^{36}$ Simpson, Is This the Promised Land, 261.

${ }^{37}$ The men in the photograph are named on the Te Papa Collections website

(https://collections.tepapa.govt.nz/object/763435), and the catalogue for On Going Out with the Tide.

${ }^{38}$ Simpson, Is This the Promised Land, 261.

39 "Am I Scared: Colin McCahon," Govett-Brewster Art Gallery, accessed September 24, 2020, https://govettbrewster.com/collection/77-3.

40 Jill Trevelyan, "Scared," https://collections.tepapa.govt.nz/object/763435.

${ }^{41}$ Curnow and Leonard, "Introduction," unpaginated.

${ }^{42}$ Pou Temara, "My Te Urewera," Urewera Mural: Colin McCahon (1999).

${ }^{43}$ Ngahuia Te Awekotuku and Linda Waimarie Nikora, "Ngā Taonga o Te Urewera. A Report prepared for the Waitangi Tribunal's Urewera District Inquiry" (2002), 10.

${ }^{44}$ Te Awekotuku and Nikora, "Ngā Taonga o Te Urewera," 24.

${ }^{45}$ Terry O'Connor, Te Manawa ō Tūhoe: The Heart of Tūhoe (Nelson: Craig Potton, 1997), 4.

${ }^{46}$ Te Awekotuku and Nikora, "Ngā Taonga o Te Urewera," 23.

${ }^{47}$ Paton, McCahon Country, 239.

${ }^{48}$ Bloem and Browne, Colin McCahon: A Question of Faith, 19.

${ }^{49}$ Tama Nikora, "Mō Te Peita a Makāna," Urewera Mural: Colin McCahon (1999).

50 "The Maori View of Colin McCahon."

${ }^{51}$ Brown, Colin McCahon: Artist, 162.

${ }^{52}$ McCahon, letter to L. S. Watt, 10 November 1975, quoted in Simpson, Is This the Promised Land, 253. 
${ }^{53}$ https://www.ngaituhoe.iwi.nz/our-history.

${ }^{54}$ Brown, Colin McCahon: Artist, 163.

${ }^{55}$ O'Connor, Te Manawa ō Tühoe, 9.

${ }^{56}$ Bloem and Browne, Colin McCahon: A Question of Faith, 224.

${ }^{57}$ Temara, "My Te Urewera."

${ }^{58}$ Paton, McCahon Country, 242. 